\title{
TOWARDS A PROFILE OF THE INTERPERSONAL ORGANIZATION of the Portuguese Clause ${ }^{1}$

\author{
(Para um perfil da organização interpessoal \\ da oração em Português)
}

\author{
Carlos A. M. GouveiA \\ (University of Lisbon E Institute for theoretical and \\ Computational Linguistics, Portugal)
}

Resumo: Este texto visa contribuir para a descrição do português do ponto de vista da Gramática Sistémico-Funcional, particularmente no que diz respeito à descrição da oração como troca. Embora assuma que a organização interpessoal da oração em português envolve fenómenos que são semelhantes em várias línguas distintas, como os sistemas de Modo oracional, por exemplo, o texto pretende ainda assim demonstrar que bá opgões de sistema (e suas realizações estruturais) que são específicas do português, sobretudo quando comparadas com as mesmas opções em inglês, uma lingua cujas descrições têm amiúde e fortemente sido impostas ao português. O texto começa com uma descriçãa geral de alguns aspectos da língua portuguesa e avança depois para uma descrição das tipologias do Modo oracional e das escolhas associadas às mesmas. Levantando algumas questões e dúvidas relativamente à descrição dos elementos que em português contribuem para a negociação e a troca, o texto acaba por propor uma descrição que encara a língua portuguesa como uma língua sem Finito, isto é, como uma língua que não tem o Finito como uma das funções do Modo oracional, já que esta sendo apropriada para a descrição da língua inglesa perde em pertinência quando pensada do ponto de vista da língua portuguesa.

Palavras-chave: troca, Modo oracional, Finito, finitude, Predicador, verbos compostos.

Abstract: This paper aims at contributing to the description of Portuguese from the point of view of Systemic Functional Grammar, particularly in relation to the description of the clause as an exchange. While assuming that the interpersonal organization of the Portuguese

1. I would like to express my deepest thanks to Luísa Azuaga, Marlene Viegas, Leila Barbara and Jim Martin for their constructive reactions to a draft of this paper. I also would like to thank the anonymous reviewers of Delta for the helpful and fruitful comments that made possible this final version. None of these people should be blamed for any inadequacy of the paper, only given credit for whatever adequacy it may have. 
clause involves phenomena that are similar across different languages, such as Mood systems, for instance, the paper wants nevertheless to show that there are systemic options (and their structural realizations) that are specific to Portuguese, particularly if compared to the same options in English, a language whose descriptions have so often and too strongly been imposed on Portuguese. Starting with a general description of some aspects of the Portuguese language, the paper then proceeds to a description of Mood types and the system of choices associated with them. By raising some questions and doubts concerning the description of the elements that in Portuguese carry the negotiation forward, the paper ends up proposing a description that sees Portuguese as a Finite-less language, that is, a language that does not have Finite, a function that proved to be appropriate for the description of the English language but fails to be so when considered from the point of view of Portuguese.

Key-words: exchange, Mood, Finite, finitess, Predicator, compound verbs.

\section{INTRODUCTION}

The purpose of this paper is twofold, since it has both a general and a specific one. Regarding the general purpose, it aims at contributing to the development of a profile of the Portuguese clause from the point of view of systemic-functional linguistics and the theory of Systemic-Functional Grammar developed by Halliday (1985; 2004), and following the profiles of other languages that have been made available recently (see Caffarel, Martin \& Matthiessen, eds., 2004). In that sense, it represents in a way the continuation of my previous work on Theme and on Reference in Portuguese (Gouveia \& Barbara, 2004; Barbara \& Gouveia, 2004). As far as its specific purpose is concerned, the paper particularly aims at establishing a description of the interpersonal organization of the Portuguese clause, paying special attention to questions of finiteness and its relation with the Predicator.

I will start, in this introduction, by generically describing some aspects of the Portuguese language, moving then, in Part 2, to a description of Mood types in Portuguese and the system of choices associated with them. In Part 3, "Finite or Predicator", I will raise some questions and doubts concerning the description of the elements that in Portuguese carry the negotiation forward, and in the following section, Part 4, I propose a description of those elements. I will finish with Part 5, where I systematize some of the conclusions drawn throughout the paper, particularly throughout Parts 3 and 4. 
Portuguese developed in the Western part of the Iberian Peninsula from the spoken Latin language brought there by the Romans from the 3rd century BC on, so-called vulgar Latin. It is therefore a Romance language, just like Spanish, French, Italian, Romanian or Catalan, for instance, from which it began to differentiate itself in the 5 th century, in consequence of the decadence and fall of the Roman Empire.

Spanning from Brazil in the Americas to Macau in Asia, Portuguese is presently spoken as a first language by some 200 million native speakers predominantly in Portugal and Brazil, but also in countries such as Angola, Mozambique, Cape Verde, Guinea-Bissau, São Tomé and Príncipe, and East Timor, which adopted it as their official language when they became independent countries. It is one of the few languages that is spoken in such widely-distributed parts of the world and it is definitely the most widely spoken language in South America, considering that Brazil alone has more than half of South America's population.

There are today two recognized standard varieties of Portuguese, European Portuguese and Brazilian Portuguese, but a third one, African Portuguese, is usually recognized to refer to the varieties spoken in Angola, Mozambique and the other African Portuguese speaking countries. The description developed in this paper is particularly focused on European Portuguese, since all the examples here discussed come from that variety, but the discussion of the clause as exchange and the conclusions drawn are valid for Portuguese in general, independently of its varieties.

In terms of the syntagmatic sequence or word order of the clause, Portuguese is an SVO language, that is, it is a language where simple declarative clauses are structured following the order Subject $\wedge$ Verb $\wedge$ Object. As a general and decontextualized characterization of a language tendency, this statement is correct, but one has to bear in mind that when analysed discursively clauses may not follow that order entirely.

The internal structure of Portuguese words is both derivational and inflectional with both types contributing also to word compounding. Apart from marking gender and number, inflectional suffixation also marks tense and mood, with the last two following three paradigms of verbal inflection. 
As in English, in Portuguese the clause is at the top of the rank-scale hierarchy, as shown in Table 1, and it is at clause rank that the systems of Mood, Transitivity and Theme are located. ${ }^{2}$

Table 1: The rank-scale constituency of Portuguese clauses

\begin{tabular}{|l|l|l|l|l|l|l|l|}
\hline Clause & Voluntários & vão & vigiar & florestas & durante & o & Verão \\
\hline & [Volunteers & will & survey & forests & during & the & summer $]$ \\
\hline Group & Voluntários & vão & vigiar & florestas & durante & o & Verão \\
\hline Word & Voluntários & vão & vigiar & florestas & durante & o & Verão \\
\hline Morpheme & Voluntário & - -s & $\ldots$ & .. & & & \multicolumn{1}{l|}{} \\
\hline
\end{tabular}

\section{Mood TYPeS}

Being an SVO language, Portuguese constructs declaratives following that order, as in "O primeiro-ministro devia antecipar a sua vinda da Venezuela" [The Prime Minister should anticipate his return from Venezuela], where "O primeiro-ministro" acts as Subject, "devia antecipar" is the verbal group, and "a sua vinda da Venezuela" is the Object.

In Portuguese there are no dummy auxiliaries for negative nor for interrogatives as there are in English. The negative is constructed with an Adjunct ("não") positioned before the verb and interrogatives are constructed either only phonologically or phonologically in conjunction with grammatical strategies (thus tone either distinguishes mood types alone or helps distinguishing them). In that respect, polar interrogatives are distinguished from declaratives by tone alone as in examples (1) and (2):

2. Unless stated otherwise, all examples given are of authentic data, either spoken or written, excluding the ones that for reasons of exposition and clarity are constructed out of the authentic ones, as it will become clear from the context. Examples may have been reduced, particularly if they were part of clause complexes and the remaining clauses in the complex were not relevant for the discussion under progress. Corpora used: Cetem-Público (written) and Coral (spoken), and daily news from the net version of the newspaper Público. Since some of my arguments are constructed in relation to Halliday's description of the English Mood system, some examples in specific parts of the paper are translations into Portuguese of examples from Halliday (2004). 


\section{Declarative - Falling tone}

(1) O primeiro-ministro devia antecipar a sua vinda da Venezuela.

The Prime-minister should anticipate his return from Venezuela

[The Prime Minister should anticipate his return from Venezuela]

\section{Interrogative - Rising tone}

(2) O primeiro-ministro devia antecipar a sua vinda da Venezuela?

The Prime-minister should anticipate his return from Venezuela

[Should the Prime Minister anticipate his return from Venezuela?]

Polar interrogatives following an order other than the SVO one are highly marked and specific to certain registers where rhetorical motivations determine the ordering of the Verb before the Subject, as in example (3):

(3) conseguirá o Sporting resistir à excelente ponta final do can-Fut the Sporting resist to the excellent effort final of the

Guimarães e salvaguardar, pelo menos, o quarto lugar no campeonato? ${ }^{3}$ Guimarães and guaranty at least the fourth position in the championship

[can Sporting resist the excellent final effort of Guimarães and get at least the fourth position in the championship?]

As far as Mood types are concerned, Portuguese distinguishes then between indicative and imperative, as shown in Figure 1, with indicative allowing for the option between declarative or interrogative. Although one may say, generally speaking, that Mood options in Portuguese are not differentiated by the ordering of functions in the clause, Mood options may in some cases be associated with different orderings of functions, but, most importantly, they may be associated with the presence or absence of certain

3. Notice the strong rhetorical motivation for the inversion registered in the interrogative: "O Belenenses já não atingirá um lugar que dê acesso às competições europeias. Perdeu ontem em Alvalade, por 3-1, e arrumou a questão, abrindo caminho a uma outra discussão, e que poderá ser bem mais interessante: conseguirá o Sporting resistir à excelente ponta final do Guimarães e salvaguardar, pelo menos, o quarto lugar no campeonato?" [Belenenses will no longer reach a position that may give it access to the European competitions. Yesterday it lost the game in Alvalade by 3-1, and settled the question, opening the way to another discussion, which may well be more interesting: can Sporting resist the excellent final effort of Guimarães and get at least the fourth position in the championship??] 
functions. In fact, whereas declaratives may be said to follow the order $\mathrm{S}$ $\wedge \mathrm{V}$ and Imperatives the order $\mathrm{V} \wedge \mathrm{S}$, the distinguishable trait between them is really the realization of an imperative with only a verb denoting either $2^{\text {nd }} P S, 2^{\text {nd }} P P$. or $1^{\text {st }} P P$, that is, only V. In Portuguese, as happens in French, according to Caffarel (2004: 94), "it is the person and number marking on the verb in the Predicator that is critical for the realization of imperative mood options".

The system distinguishes between an exclusive imperative and an inclusive one, depending on whether it is oriented towards only the addressee(s), in the case of the exclusive type, or towards both the speaker and the addressee(s), as in the case of the inclusive type, which is thus only plural (you and I). The exclusive type may be both singular and plural (Faz! vs. Façam!/ Do it'), and each type may be formal or informal: formal singular would be Faça! [Do it'] as opposed to the informal singular Faz! [Do it'], whereas formal plural would be Fazei! [Do it! $]$ as opposed to the informal plural Façam! [ $D_{0}$ itt']. The exclusive informal plural form may also be used with a polite vocative in formal contexts: Façam, Senhores! [Do it, Sirs'].

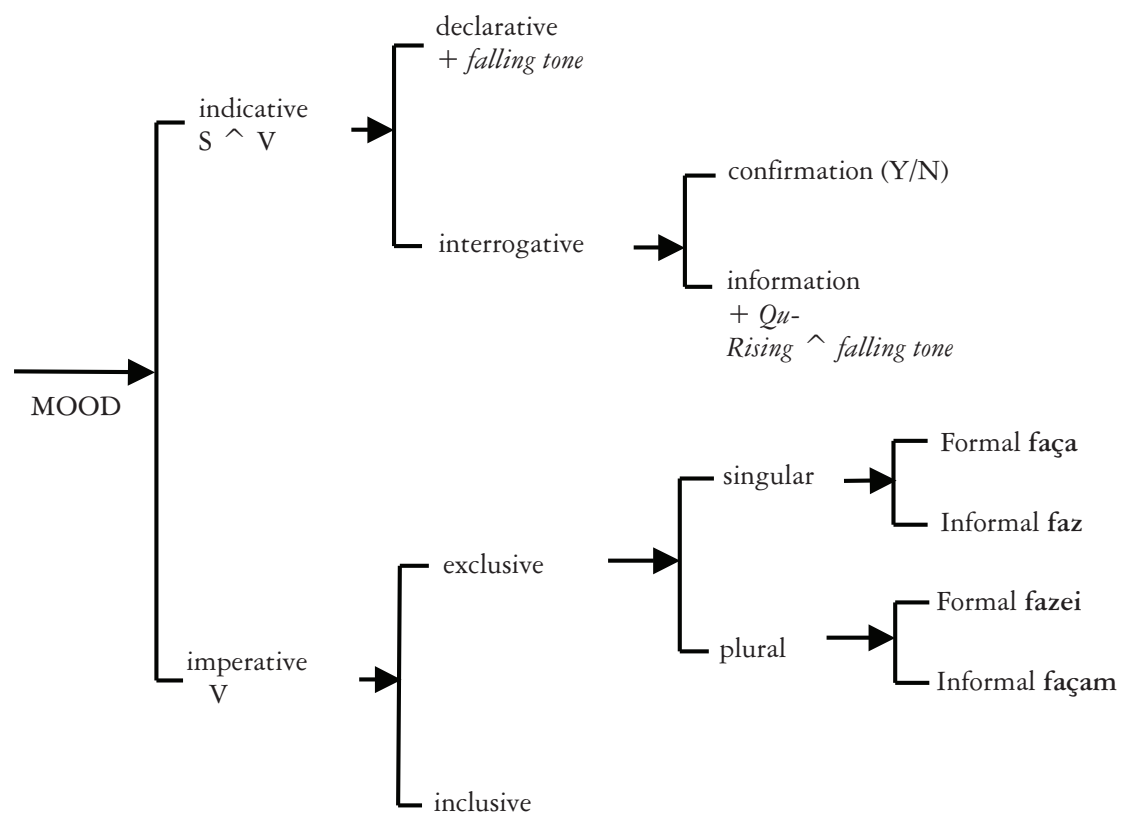

Figure 1: Mood options in Portuguese. 
The absence of a lexically realized Subject is quite common in dialogic negotiation, that is, most of the times Portuguese does not need to have a Noun or a substituting pronoun performing the structural function of Subject. Being easily deduced by either/both the context (it is there, it is being talked about) or/and the co-text (number agreement), the Subject is therefore more a semantic trend in the discourse than a formal category. In most cases this semantic trend may be converted into a formal category in textual fragments where it had no formal realization originally; compare, for instance, example (4), with no Subject realized lexically, with example (5), where I have inserted a lexical item realizing the function of Subject. The structure in (5) is not seen as redundant due to the presence of a formal element acting as Subject, nor is the original structure in (4) seen as incomplete due to its absence.

(4) Durante a sua curta gestão, fez aprovar 140 leis e decretos. During the his/her short management made approve 140 laws and statutes [During his short governance, he got approved 140 laws and statuses]

(5) Durante a sua curta gestão, Ieltsin/ele fez aprovar 140 During the his/her short management Yeltsin/he made approve 140

leis e decretos.

laws and statutes

[During his short governance, Yeltsin/he got approved 140 laws and statuses]

In terms of discourse semantics it is quite irrelevant whether you have a formal element realizing Subject or not, particularly if that presence or absence happens across different clause complexes. Nevertheless, there are cases in Portuguese where the formal presence of the Subject is required, in exactly the same way as there are cases where its absence is structurally required and seen as obligatory. The first cases happen, for instance, when there is a change in the discourse and a new Theme/Subject is introduced ${ }^{4}$; the second when in the same clause complex there is more than one clause with the same Subject.

4. This is particularly relevant in cases where the change of Subject does not represent a change in number and in person. In order to avoid ambiguity with the previous Subject the new one has to be nominated, that is, it has to be introduced by a Noun. 
It is the latter of these two cases, the ones where the absence of Subject is structurally required and seen as obligatory, that make tagging an impossible criterion to probe the Subject in Portuguese. What I mean is that the apposition of a tag question to a clause transforms that clause into a clause complex and the absence of the Subject in the second clause (the tag one) is structurally constrained to prevent redundancy. Notice for that matter that: i) the use of a tag question with either (4) or (5) will not probe the Subject, no matter whether the Subject is present, as in (5), or absent, as in (4) - see the resulting examples in (6) and (7) below; and ii) the insertion of the Subject in the tag, following the possibility described above when a Subject was introduced in (4), thus creating (5), is not possible here, as the clause complex thus created will be seen as grammatically incorrect - see the resulting examples in (8) and (9):

(6) Durante a sua curta gestão, fez aprovar 140 leis e During the his/her short management made approve 140 laws and decretos, não fez? statutes, not did

[During his short governance, he got approved 140 laws and statuses, didn't he?]

(7) Durante a sua curta gestão, Ieltsin/ele fez aprovar 140 During the his/her short management Yeltsin/he made approve 140

leis e decretos, não fez?

laws and statutes, not did

[During his short governance, Yeltsin/he got approved 140 laws and statuses, didn't he?]

(8) *Durante a sua curta gestão, fez aprovar 140 leis e During the his/her short management made approve 140 laws and decretos, ele não fez? statutes, he not did [During his short governance, he got approved 140 laws and statuses, didn't he?]

(9) *Durante a sua curta gestão, Ieltsin/ele fez aprovar 140 During the his/her short management Yeltsin/he made approve 140 leis e decretos, ele não fez? laws and statutes, be not did

[During his short governance, Yeltsin/be got approved 140 laws and statuses, didn't he?] 


\section{Finite or Predicator?}

From what I have said so far, it seems clear that the grammatical criterion for identifying the Subject will be person and number agreement with the (Finite and/or) Predicator but not tagging. And apart from not being a criterion to probe the Subject, tagging is not also a criterion to probe the Finite, contrary to what happens in English. This may either be seen as the direct outcome of the Finite being regularly conflated/fused with the Predicator with the tag not working as a Finite-Predicator splitting instrument, or the result of Portuguese not having the function of Finite at all, and the negotiation being thus carried out by the Predicator. Consider in relation to this example (10), here also presented with a direct structural translation:

(10) O Duque deu o bule, não deu? The Duke gave away the teapot, not gave? [The Duke's given away that teapot, hasn't he?]

Examples like (10), a fairly regular wording in Portuguese, despite being a translation of mine into Portuguese of an example taken from Halliday (1994: 71), clearly show the importance the Predicator has in Portuguese, allowing us to say that it is the Predicator and not the Finite that helps carrying on the negotiation. Furthermore, considering the characteristics of the Finite in English, as stated by Halliday (2004: 115-116), one may actually say that in Portuguese those characteristics are mainly associated with the Predicator:

The Finite element, as its name implies, has the function of making the proposition finite. That is to say, it circumscribes it, it brings the proposition down to earth, so that it is something that can be argued about. A good way to make something arguable is to give it a point of reference in the here now; and this is what the Finite does. (...). Finiteness is thus expressed by means of a verbal operator which is either temporal or modal. But there is one further feature which is an essential concomitant of finiteness, and that is polarity.

In the vast majority of the cases, Portuguese uses only the Predicator to do what the Finite and the Predicator do in English. In fact, we can actually say that although in Portuguese tagging is not a criterion to probe the Subject or the Finite, it is a criterion to probe the Predicator and its 
finiteness. Therefore, instead of assuming that in Portuguese the Finite is regularly conflated/fused with Predicator (see, for instance, Basílio \& Basílio, 2000; or Basílio, 2003), we should actually ask whether Portuguese uses the Finite function at all? Analysing some exchange in Portuguese or going back to the Hallidayan example given in (10) may actually help us answering that question. So, in Table 2 I present an example of a naturally occurring exchange between two speakers of Portuguese and in the leftend column of Table 3, I have reproduced the original Hallidayan example presented in (10), this time followed by the remaining examples in the exchange ${ }^{5}$, and in the right-end column I added a possible Portuguese version of the entire exchange.

For the sake of clarity, let me just add that in the exchange in Table 2 speakers A and B are comparing maps and talking about how to get from one place into another by way of comparing one's map to the other's.

Table 2: Example of a naturally occurring exchange in Portuguese6

A: O início é junto a uns eucaliptos jovens.

The beginning is close to some eucalyptus young

[The beginning is close to some young eucalyptus]

B: Sim, também tenho eucaliptos jovens.

Yes also have eucalyptus young

[Yes, I've got also young eucalyptus.]

A: OK. Pronto. Depois segues em frente em direcção a uma curva e vais OK Fine Then follow in ahead in direction to a curve and go encontrar um centro de piscicultura.

find a centre of fish farming

[OK. Fine. Then you go straight ahead to a curve and you'll find a fish farming centre.]

B: Centro de piscicultura, não tenho.

Centre of fish farming NEG have

[I haven't got a fish farming centre.]

A: Que é que tens?

What is that have

[What have you got?]

5. The set of examples was reduced in size, for reasons of economy.

6. In all cases the Predicator is $\mathrm{V}+$ Tense + Number inflection. 
B: Aqui ao pé, tenho uma grade de ferro. A única coisa que eu tenho. Tu tens? Here close have one fence of iron The only thing that I have. You have [Around here I have got an iron fence. That's the only thing I've got? Have you got it?]

A: Pronto. Tenho isso um bocadinho mais à frente, primeiro tenho

Fine have that one little bit further ahead first have

[Fine. I have got that a bit further away. First I've got

o centro de piscicultura, depois tenho a grade de ferro.

the centre of fish farming then have the fence of iron

the fish farming centre and then the iron fence.]

The entire negotiation in Table 2 is centred in the Predicator (identified with bold in the examples), in the sense that it is the Predicator that is either repeated or changed as the exchange goes on, carrying with it the characteristics of clause finiteness. Furthermore, it should be noted that in all examples but one the corresponding tag would have to pick up the Predicator. The exception to that is the second Predicator in the second line of speaker A, vais encontrar [you'll find], as the tag would pick up only the first element (vais) of the verbal group acting as Predicator (vais encontrar).

In much the same way, in our reading of the data in Table 3 it should be observed that in all the instances but one where we have the Finite in English, in Portuguese we have the Predicator and it is the Predicator that carries the characteristics of clause finiteness. The exception to that is the final exchange where there are two possibilities in Portuguese to express the finite temporal aspect of future: (ele) dará (future tense) and (ele) vai dar (compound present tense), with the former more associated with written language and the latter with both written and spoken language. This possibility of choosing between the future tense and the compound present tense was also available for speaker $\mathrm{A}$ in the exchange in Table 2: the choice between the potential form encontrarás [you will find] and the actually chosen vais encontrar [you're going to find]. 
Table 3: Mood exchange in English and Portuguese

\begin{tabular}{|c|c|}
\hline English & Portuguese $^{1}$ \\
\hline - The Duke's given away that teapot, hasn't he? & - O Duque deu o bule, não deu? \\
\hline - Oh, has he? & $\begin{array}{l}\text { - Deu? } \\
\text { give (rising t.) } \\
\text { [Has be?] }\end{array}$ \\
\hline - Yes, he has. & $\begin{array}{l}\text { - Sim, deu. } \\
\text { Yes give (fall. tone) } \\
\text { [Yes, he has.] }\end{array}$ \\
\hline - No, he hasn't! & $\begin{array}{l}\text { - Não deu nada. } \\
\text { NEG give NEG } \\
{[N o \text {, be basn't. }]}\end{array}$ \\
\hline - He hasn't; but he will. & $\begin{array}{l}\text { - Não deu; mas dará / vai dar } \\
\text { NEG give; but will give/ is going to give } \\
\text { [He basn't; but he will is going to }]\end{array}$ \\
\hline
\end{tabular}

The use of at least one compound tense in both the exchanges, curiously enough the same one in both, the present compound tense expressing the idea of future, might suggest that in Portuguese we can after all have both a Finite and a Predicator. Since in these cases the first verbal element (the auxiliary) carries finiteness, and the second verb, used in the infinitive, carries a fully lexical meaning, then it could be argued that the first verbal form is the Finite and the second is the Predicator. However, before jumping to conclusions, one must acknowledge that what was being negotiated has in fact changed in both the exchanges. In its final part the exchange in Table 3 gets changed because the occurrence of an event in the past is not the same as the possibility of its occurrence in the future. We can therefore say that during the entire exchange in Portuguese it is the Predicator that is carrying the negotiation forward. With the change of tense a new exchange begins and with it a new negotiation is developed (with a new Finite in English and a new Predicator in Portuguese).

As for the case of the exchange in Table 2, the use of the compound tense is not only connected to a change in tense, from present to future, but also to a change in the type of information being exchanged: "going and finding" instead of "having". 
Now, getting back to the actual differences between the use of the future tense and the compound present tense, let us consider examples (11) and (12), derived from the ones in Table 3, one using one tense and another using the other:

(11) O Duque dará o bule, não dará? The Duke will give (away) the teapot, not will give [The Duke will give the teapot (away), won't he?]

(12) O Duque vai dar o bule, não vai? The Duke is going to give (away) the teapot, not is going [The Duke is going to give the teapot (away), isn't he?]

Now, as can be seen from example (11), when we have the simple future tense, that is, neither a compound tense nor a compound verb, the Predicator gets to be repeated in the tag, and there is no sign of a Finite element either in the main clause or in the tag. In this case, the Predicator seems to carry all the relevant information. Example (12), on the contrary, seems more like its English equivalent, that is, it is an example in which we have both a Finite and a Predicator, each doing different things in the clause, with the Finite being picked up later in the tag. Developing further this line of thinking let us consider in Table 4 the possible negative answers to the tag questions in (11) and (12), both in English and in Portuguese.

Table 4: Possible negative answers to the tag questions in (11) and (12)

\begin{tabular}{|l|l|}
\hline English & Portuguese \\
\hline $\begin{array}{l}\text { The Duke will give the teapot (away), won't he?] } \\
\text { No, he has already. } \quad[\mathrm{S}+\mathrm{F}] \\
\text { No, he has given it already. } \quad[\mathrm{S}+\mathrm{F}+\mathrm{P}+\mathrm{C}]\end{array}$ & $\begin{array}{l}\text { O Duque dará o bule, não dará? } \\
\text { Não, já deu. } \quad[\mathrm{P}] \\
\text { Não, já o deu. } \quad[\mathrm{C}+\mathrm{P}]\end{array}$ \\
\hline $\begin{array}{l}\text { The Duke is giving the teapot (away), isn't he? } \\
\text { No, he has already. } \quad[\mathrm{S}+\mathrm{F}]\end{array}$ & $\begin{array}{l}\text { O Duque vai dar o bule, não vai? } \\
\text { Não, já deu. } \quad[\mathrm{P}] . \\
\text { No, he has given it already. já deu. } \quad[\mathrm{C}+\mathrm{P}+\mathrm{F}+\mathrm{P}+\mathrm{C}] \\
\text { *Não, já foi. }\end{array}$ \\
\hline
\end{tabular}

In both examples, English uses Subject and Finite in the answers ( $\mathrm{He}$ has already); an alternative to that would be to use also the Predicator, 
in which case the Complement will have to come along (He has given it already). In Portuguese, the case is rather different. Apart from not using the Subject, as we have already seen, Portuguese uses a verb form which despite its finiteness has more to do with the function of the Predicator in English than with the function of Finite. The second example of Portuguese in Table 4 is clear in that respect. Even if it were argued that we have two functions in the main clause, Finite (vai) and Predicator (dar), with the Finite being recovered in the tag, in the possible negative answers to the tag what we have is the recovering of the element playing Predicator, not the element playing Finite, as happens in English. As a matter of fact, in Portuguese one cannot use the element that in the main clause is playing what might be argued to be Finite. So, in Portuguese one has to use deu, the fully lexical verb with the required inflection for this case, not foi, the auxiliary verb with the required inflection. An answer like Não, já foi cannot be used in this context as it presupposes a total different question motivating it, such as, for example, O Duque vai a Lisboa, não vai? [The Duke is going to Lisbon, isn't he? ], where the verb is used with its full lexical meaning corresponding to the verb go in English.

So far we have observed that contrary to what happens in English, in Portuguese the Predicator plays an important role in the negotiation of the exchange. This is not exclusive to Portuguese, since it happens also in French, as Caffarel (1995 and 2004) has already shown, and whose words are worth quoting (2004: 94):

As far as the modal structure of the French clause is concerned, we have seen (...) that the Predicator is critical both in the imperative and indicative mood. It is the absence of Finite in the imperative that differentiates it from the indicative mood. In dialogues, negotiating the resolution of the exchange involves the replaying or ellipsis of the interpersonal functions of Subject, Finite and Predicator. As a general rule, these three functions are crucial both to the negotiation process in French and to the realization of indicative MOOD options (see Caffarel 1995/1997). In view of this, I have referred to the part of the clause which is comprised of these three functions as the Negotiator of the clause. (...). The overall modal structure of French consists of the Negotiator and what I refer to as the Remainder, which comprises Complements and circumstantial Adjuncts (...).

Why Caffarel has chosen to introduce new functional categories to describe French, instead of using the ones available to describe English Mood and Residue - is something that I will not discuss here, but it seems 
obvious that the basic motivation for that choice was the role the Predicator plays in the negotiation of the exchange in French, where it cannot be seen as a residual element. The difference between Caffarel's proposal for the description of French and the description that I have tentatively introduced so far is that in Portuguese we not only have a Predicator playing a central role in the exchange negotiation, but we do not appear to have a Finite element at all.

Therefore, if French, following Caffarel (1995; 2004), has two basic functions of Mood, the Negotiator and the Remainder, Portuguese will have the same basic functions. The difference between the two languages would be that the Negotiator comprises different functions in the two languages whereas the Remainder comprises the same functions in both of them. While in French the presence of Subject, Finite and Predicator make up the Negotiator, in Portuguese the same function would be made up of only the Subject and the Predicator, as shown in Table 5:

Table 5: The basic functions of Mood in Portuguese, if following Caffarel's proposal for French

\begin{tabular}{|c|c|c|c|}
\hline Subject & Predicator & Complement(s) & Circ. Adjunct(s) \\
\hline \multicolumn{2}{|c|}{ Negotiator } & \multicolumn{2}{|c|}{ Remainder } \\
\hline
\end{tabular}

In that respect Portuguese would be closer to Vietnamese than to French, if one is to follow Thai's (2004) description of Vietnamese. In fact, in a move clearly connected to that of Caffarel (1995 and 2004), Thai (2004: 411-412) chooses to label the Mood functions of the Vietnamese clause along the same lines as Caffarel did in relation to French and assumes the absence of a Finite function in Vietnamese:

I call the elements of the clause that carry the argument forward Negotiatory elements and the rest of the clause (which does not include these elements) the Remainder.

In other words, the vietnamese clause as exchange consists of two functional components: Negotiatory elements, which have the function of carrying the argument forward; and the Remainder, which can be left out when the argument is in progress. (...). Structurally, the Negotiatory element consists of the Predicator and the Negotiator. The Predicator is realized by a verbal group in Vietnamese. (...). 
The Negotiator is realized by one of the interpersonal particles: polar interrogative particles, elemental interrogative items or imperative particles. (...). A Predicator on its own realizes the option 'declarative' (...).

This absence of Finite in Vietnamese is also referred to by Matthiessen (2004: 548) who compares the negotiation of polarity in Vietnamese to the same type of negotiation in Spanish, since in both languages the negotiation can be carried out by the Predicator: in one case without Finite (Vietnamese); in the other without Subject (Spanish):

(...) in Spanish, the polar value of the clause can be negotiated through Finite/ Predicator alone (without Subject); and in this respect it is similar to languages without a Finite element where the Predicator carries the negotiation of polarity, as with Chinese and Vietnamese (...).

Notice that what is being referred to by Matthiessen in relation to Spanish is similar to what we have identified in Portuguese concerning the same reality, that is, the possibility of not having the Subject lexically realized in the clause. But that cannot be compared to the absence of Finite in Vietnamese. Spanish and Portuguese do have the function of Subject, which may or may not be deployed in the clause, whereas Vietnamese does not have the function of Finite at all. And since Portuguese, does not seem to have a Finite function as well, one can say following Matthiessen's above quote that in Portuguese the negotiation of polarity is carried out by the Predicator alone or by the Predicator together with the Subject.

Picking up the examples taken from Halliday (1994: 71) and presented in Table 3 above with the corresponding usage in Portuguese, let us now consider also an example of Vietnamese taken from Thai (2004: 410).

Looking at Table 6 helps us understand how Portuguese is closer to Vietnamese than it is to English, when it comes to the function of Finite. In both languages it is the Predicator that is in the centre of the interpersonal exchange thus helping to carry the negotiation forward.

I am well aware that one cannot state that Portuguese is a Finite-less language like Vietnamese based only on the above fragmentary and basic comparison of the two languages, particularly if one is also to consider the existence of clauses like the last example in Table 3 and to which I have already drawn attention in example (12): vai dar as opposed to dará. 
Table 6: Mood exchange in English, Portuguese and Vietnamese

\begin{tabular}{|c|c|c|}
\hline English & Portuguese & Vietnamese \\
\hline $\begin{array}{l}\text { - The Duke's given away that } \\
\text { teapot, hasn't he? }\end{array}$ & $\begin{array}{l}\text { - O Duque deu o bule, não } \\
\text { deu? }\end{array}$ & $\begin{array}{l}\text { - Han di Saigon } \\
\text { He go Saigon } \\
\text { [He has gone to S.] }\end{array}$ \\
\hline - Oh, has he? & $\begin{array}{l}\text { - Deu? } \\
\text { give (rising t.) } \\
\text { [Has be? }]\end{array}$ & $\begin{array}{l}\text { - Di chua? } \\
\text { go INT } \\
\text { [Has be?] }\end{array}$ \\
\hline - Yes, he has. & $\begin{array}{l}\text { - Sim, deu. } \\
\text { Yes give (fall. tone) } \\
\text { [Yes, he has.] }\end{array}$ & $\begin{array}{l}\text { - Di roi } \\
\text { go AFFIRM } \\
\text { [He has. }]\end{array}$ \\
\hline - No, he hasn't! & $\begin{array}{l}\text { - Não deu nada. } \\
\text { NEG give NEG } \\
{[N o \text {, be hasn't. }]}\end{array}$ & $\begin{array}{l}\text { - Chua di dau } \\
\text { NEG go NEG } \\
\text { [He hasn't.] }\end{array}$ \\
\hline
\end{tabular}

Also, in these cases, where we have a compound verb being used, we do have the first verb in the verbal group carrying the marks of finiteness, that is, it is this verb that is limiting the clause in terms of tense, number and person, whereas the second verb shows no finiteness. These are common cases in Portuguese. In fact, the existence in Portuguese of a large number of verbs that can be used as auxiliaries in compound verbal structures allows for a growing number of periphrastic constructions with aspectual, temporal or modal meaning - see the (b) examples in (13)-(15), taken from Cunha \& Cintra, 1984: 395-396, and their "corresponding" simple constructions in examples (a):

\begin{tabular}{|c|c|c|}
\hline temporal & $\begin{array}{l}\text { (13a) O navio partirá. } \\
\text { (13b) O navio vai partir. }\end{array}$ & $\begin{array}{l}\text { [The vessel will depart.] } \\
\text { [The vessel is going to depart.] }\end{array}$ \\
\hline aspectual & $\begin{array}{l}\text { (14a) } \mathrm{O} \text { avião aterrou. } \\
\text { (14b) } \mathrm{O} \text { avião acabou de aterrar. }\end{array}$ & $\begin{array}{l}\text { [The plane landed. }] \\
\text { [The plane has just landed.] }\end{array}$ \\
\hline modal & $\begin{array}{l}\text { (15a) Farei exercícios. } \\
\text { (15b) Tenho de fazer exercícios. }\end{array}$ & $\begin{array}{l}\text { [I will do exercises. }] \\
\text { [I have to do exercises. }]\end{array}$ \\
\hline
\end{tabular}

Made up of a lexical verb, either in the gerundive, infinitive or participle form, preceded by a verb emptied of its normal lexical content, these 
constructions are referred to in the literature as verbal locutions, fixed/ frozen expressions, compound verbs and periphrastic constructions (see Cunha \& Cintra, 1984; Mateus et al., 1989; Ranchod, 2003).

How are we to describe these constructions? Are they constructions where we have a Finite and a Predicator, or constructions where we have a complex Predicator? I would argue, following what has been implied in the line of thinking presented so far, that these are cases where we have a complex Predicator, even if: i) only one of the verbal operators in the complex is marked for person, number and tense (as happens with all verbal structures made up of more than one verb); ii) the verbal operator that is marked for person, number and tense is the auxiliary not the verb denoting the process; and iii) it is the verb that is marked for person, number and tense, that is, the auxiliary, that most of the times, though not always, gets to be repeated when negotiation is carried on.

Following Halliday (2004), any attempt to systematize what the Finite does in English, that is, what its characteristics and uses are, will end up with more or less six aspects. If we are to think about these six uses/ characteristics of the Finite in English as characteristics associated with one single function in Portuguese performed by an auxiliary or a modal verb, and picking up some of the arguments presented so far, we will conclude that there is not one single function/auxiliary or modal verb combining all these aspects. In English, the Finite is used (i) to distinguish tense (primary tense), and we could actually say that the same happens in Portuguese, either in the auxiliary/ modal verb or in the Predicator. In English, the Finite is used (ii) to express modality, and again we could actually say that the same happens in Portuguese, whenever we have a modal verb. In English, the Finite is used (iii) to distinguish polarity, but we cannot say that the same happens in Portuguese, since polarity (negative) is distinguished in Portuguese by the use of an adverb of negation. In English, the Finite is used (iv) separately in most verbal forms except in the simple past and simple present tenses of active (voice), positive (polarity) and neutral (contrast) clauses, whereas in Portuguese, if we are to accept that the auxiliary has the function of Finite, it would only exist as a separate function in compound verbs. In English, the Finite is used (v) in conjunction with the Subject to distinguish declaratives $(S \wedge F)$ from interrogatives $(F \wedge S)$, but there is no such thing in Portuguese, a language that distinguishes declaratives from interrogatives by way of using a falling or rising tone, respectively. 
And, finally, in English, the Finite is used (vi) with the Subject alone to produce tag questions, whereas the mere existence of tags in Portuguese is something that is arguable, as there is not a general pattern of use as there is in English; and even if we accept that the existence of tags is something quite regular in Portuguese, the tag does not pick up the Finite and the Subject as single isolated functions: that would only happen in compound verbs and only if one considers that the auxiliary is playing the function of Finite, as in all the remaining cases the verbal form in the tag matches exactly the one used in the main clause.

\section{The Predicator as the negotiation mover}

If we are to consider the clause and its interpersonal functions, it seems obvious from the arguments presented so far, that the Finite is not a function of the clause in Portuguese. Finiteness, which is carried by the Finite in English, is rather a characteristic of the Predicator in Portuguese, that is, it is contained in the Predicator and not fused or conflated with it as happens in certain cases with the Finite in English. If one thing is contained in another, it is understood as being a part of that other thing whereas if it is fused, it is understood as having an existence of its own whatever its possible realizations. And finiteness has no independent existence from the Predicator in Portuguese, it is part of it.

Finiteness is therefore a characteristic or a function that in Portuguese does not work at clause rank, but at the group rank. Whenever the Predicator is complex, the main verb assumes an infinitive, gerundive, or past participle form and transfers its finiteness to the auxiliary verb, whose function is to further specify aspects of temporal, aspectual or modal value to the complex, apart from the marking of person, number and tense normally contained in a simple Predicator. In other words, if the Predicator is a simple one, it carries with it the marks of number, person and tense; if it is a complex one, then it is the first element that carries with it those marks and the second element carries with it secondary tense. These changes in the functions of the verb elements are motivated at group rank, not clause rank.

In view of what I have said so far, I will refer to the simple or complex verbal group that carries on the negotiation the Predicator. Together with 
the Subject, the Predicator constitutes the Mood of the Portuguese clause as an exchange, and the remaining elements of the clause constitute the Residue, as shown in Table 7.

Table 7: The basic functions of Mood in Portuguese

\begin{tabular}{|c|c|c|c|}
\hline Subject & Predicator & Complement(s) & Circ. Adjunct(s) \\
\hline \multicolumn{2}{|c|}{ Mood } & \multicolumn{2}{|c|}{ Residue } \\
\hline
\end{tabular}

Since it may be realized by a verbal group complex and not only by a single verb, the Predicator may be looked at from the point of view of its internal structure, to see what functions the elements are playing inside the structure. Though tempting if one is interested in constituency and dependency, that possibility is totally irrelevant here. In fact, when dealing with verbal group complexes and the function the elements play in the complex, it will be important to distinguish their different functions, but in interpersonal terms what is important is the fact that the negotiation is carried on by either the Subject and the Predicator or the Predicator alone. And for that it does not matter if the Predicator is made of a simple or a complex verbal group, as represented in Figure 2.

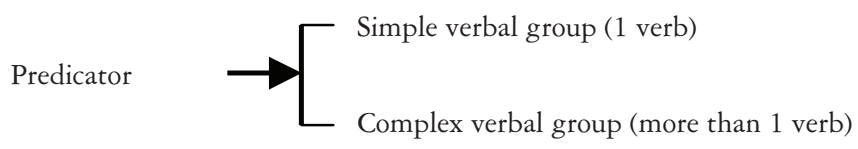

Figure 2: Predicator options in Portuguese.

Of course, we can always say that it is the first verb in the Predicator that carries tense and modality or that the Adjunct of polarity is placed before that first verb, with first being here understood as meaning either single element or one in a series. But somehow it seems more relevant to say that in Portuguese it is the Predicator that carries out the negotiation of polarity and realizes both primary and secondary tense, and modality; or 
that negative polarity is marked with the Adjunct "não" before the Predicator, whether this one is made up of a simple or complex verbal group".

What I have said so far particularly applies when describing the Indicative mood in Portuguese. Before systematizing the conclusions, one final comment should therefore be made concerning the Imperative Mood. As shown in Figure 1 in Part 2 of this paper there are five imperative options in Portuguese. It should be added, though, that those five options may be doubled to ten, when the difference between a simple Predicator and a complex Predicator is brought into the picture. In fact one may say that in Portuguese there are five imperative options with a simple Predicator [V+infl] and five imperative options with a complex Predicator. In both cases, three of the forms are plural and two are singular. A distinction between inclusive imperatives and exclusive ones can also be made, and was dealt with in part 2 of this paper. As already mentioned, when using an inclusive imperative speakers include themselves in the action being commanded, whereas with an exclusive imperative they are commanding someone to do something without including themselves in the realization of the action.

Now, the difference between an imperative with a simple Predicator and an imperative with a complex Predicator, is a difference between issuing a command as such and a command with the illocutionary force of an exhortation, hence the distinction between Commanding Imperatives and Exhorting Imperatives, as represented in Table 8:

Table 8: Examples of the two types of Imperative in Portuguese

\begin{tabular}{|l|l|}
\hline COMMANDING & EXHORTING \\
\hline Cante $\quad$ ssing + 2nd PS $]$ & Vá cantar! [go + 2nd PS sing $]$ \\
Canta! [sing + 2nd PS $]$ & Vai cantar! [go + 2nd PS sing] \\
Cantai! [sing + 2nd PP $]$ & Ide cantar! [go + 2nd PP sing $]$ \\
Cantem! [sing + 2nd PP $]$ & Vão cantar! [go + 2nd PP sing $]$ \\
Cantemos! [sing + 1st PP $]$ & Vamos cantar! [go + 2nd PP sing $]$ \\
\hline
\end{tabular}

7. I am well aware that certain cases with the modal verbs poder and dever admit the Adjunct of polarity between the verbs of the complex. The insertion of the Adjunct of Polarity between two verbs results in a different meaning, as the following examples clearly show:
(a) Posso fazer isso.
[I can/may do that.]
(b) Não posso fazer isso.
[I cannot do that.]
(c) Posso não fazer isso.
[I may not do that.]
(d) Não posso não fazer isso.
[I cannot not do that.] 
The use of the auxiliary $\operatorname{Ir}$ [to Go] in conjunction with a main verb, as in the examples in the second column in Table 8, functions as a softener of the command, which may be said to be more of the exhorting kind than of the commanding one. The use the auxiliary-like verb $I r$ in an example like Vamos cantar! turns the whole action into an exhortation corresponding more or less to the English construction Let's sing!, which "realizes a suggestion, something that is at the same time both command and offer", as Halliday (2004: 139) puts it, or an exhortation as I put it. This type of construction that is at the same time command and offer finds realization in all five imperative options in Portuguese, as can be seen from Table 1.

Considering than in both cases of imperatives (commanding and exhorting) in Portuguese there is no temporal reference to the speech event and that the absence of Finite in the case of commanding types is usually explained by the fact such clause types do not specify that reference (cf. Caffarel, 2004: 93), it seems obvious to consider Vamos cantar! as a Predicator with a complex verbal group rather than a Finite plus a Predicator as it tends, unfortunately, to be classified. The same can be said about constructions such as the one in (14b) above ( $O$ avião acabou de aterrar), which also tends, unfortunately, to be treated as Finite plus Predicator.

\section{Conclusion}

With this paper I wanted to contribute to a description of Portuguese from the point of view of Systemic Functional Grammar, particularly in relation to the description of the clause as an exchange. While assuming that the interpersonal organization of the Portuguese clause involves phenomena that are similar across different languages, such as Mood systems, for instance, I wanted nevertheless to show that there are systemic options (and their structural realizations) that are specific to Portuguese, particularly if compared to the same options in English, a language whose descriptions have so often and too strongly been imposed on Portuguese.

Starting the paper by generically describing some aspects of the Portuguese language, I then proceeded to a description of Mood types and the system of choices associated with them. By raising some questions and doubts concerning the description of the elements that in Portuguese carry the negotiation forward, I ended up proposing a description that 
sees Portuguese as a Finite-less language, that is, a language that does not have Finite, a function that proved to be appropriate for the description of the English language but fails to be so when considered from the point of view of Portuguese. Furthermore, the role the Predicator plays in the negotiation of the exchange in Portuguese, whether that negotiation involves only polarity, modality or tense, or a combination of any of these, certainly characterizes the Predicator as a fundamental function of the clause and not a residual one as happens in English.

By showing that finiteness is a characteristic of the Predicator in Portuguese, in the sense that it is contained in the Predicator and not fused or conflated with it, I hope I have contributed to a more accurate description of what is involved in the negotiation of an exchange in Portuguese. In fact, having no independent existence from the Predicator, contrary to what happens in English, finiteness is a characteristic or a function that in Portuguese does not work at clause rank, but at the group rank, since it is at group rank that aspects of temporal, aspectual or modal value are specified.

Recebido em dezembro de 2008 Aprovado em fevereiro de 2009 E-mail: carlos.gouveia@fl.ul.pt

\section{REFERENCES}

Barbara, L. \& C. A. M. Gouveia (2004): It is not there, but [it] is cohesive: the case of pronominal ellipsis of subject in Portuguese. In BANKs, D. (ed.): Text and Texture: Systemic Functional viewpoints on the nature and structure of text. Paris: L'Harmattan: 159-172.

Basílio, C. \& Rita Basílio (2000): A Palavra: Realidade Interdimensional. Leiria: Editorial Diferença.

Basílıo, C. (2003): A mútua implicação das dimensões semânticas no discurso de Thomas Traherne: incidências no processo de tradução (uma aplicação da "teoria das verbalizaçoes" de M.A.K. Halliday). PhD Thesis, University of Aveiro, Portugal.

Caffarel, A. (1995): Approaching the French Clause as a Move in Dialogue: Interpersonal organization. In HASAN, R. \& P. Fries (eds.): On Subject and Theme: a Discourse Functional Perspective. Amsterdam: John Benjamins: 1-49). 
Caffarel, A. (2004): Metafunctional Profile of the Grammar of French. In Caffarel, A., J. R. Martin \& C. M. I. M. Matthiessen (eds.): 77137.

Caffarel, A., J. R. Martin \& C. M. I. M. Matthiessen (eds.). (2004): Language Typology: A functional perspective. Amsterdam: John Benjamins.

Cunha, C. \& L. F. L. Cintra (1984): Nova Gramática do Português Contemporâneo. Lisboa: Edições João Sá da Costa.

Gouveia, C. A. M. \& L. Barbara (2004): Marked or unmarked that is NOT the question, the question is: Where's the theme?. In HeberLe, V. \& J. L. Meurer (eds.): Systemic Functional Linguistics in Action. Ilha do Desterro: A Journal of English Language, Literatures in English and Cultural Studies, 46: 155-177 (Previously published as Direct Paper 45. S. Paulo: PUCSP, 2001).

Halliday, M. A. K. (1985): An Introduction to Functional Grammar. London: Arnold.

Halliday, M. A. K. (1994): An Introduction to Functional Grammar. $2^{\text {nd }}$ Ed.. London: Arnold.

Halliday, M. A. K. (2004): An Introduction to Functional Grammar. $3^{\text {nd }}$ Ed. revised by C. M. I. M. Matthiessen. London: Arnold.

Mateus, M. H. M. et alii (1989): Gramática da Língua Portuguesa. 2a edição revista e aumentada. Lisboa: Caminho ( $3^{\text {a }}$ ed., 1992).

Matthiessen, C. M. I. M. (2004): Descriptive motifs and generalizations. In Caffarel, A., J. R. Martin \& C. M. I. M. Matthiessen (eds.): 537-673.

RanchHod, E. M. (2003): O Lugar das Expressões "Fixas" na Gramática do Português. In Castro, I. e I. Duarte (eds.): Razões e Emoção. Miscelânea de estudos oferecida a Maria Helena Mira Mateus. Lisbon: INCM: 239-254.

Thai, M. D. (2004): Metafunctional Profile of the Grammar of Vietnamese. In Caffarel, A., J. R. Martin \& C. M. I. M. Matthiessen (eds.): $397-$ 431.

Thompson, G. (2004): Introducing Functional Grammar. 2nd Ed., London, Arnold. 